\title{
Using Technological Applications as an Independent Learning Strategy to Support Vocabulary Acquisition for Secondary Students with Learning Disabilities
}

\author{
Donna M. Egan, Lina Gilic \\ The School of Education, Suny Old Westbury, New York, USA \\ Email: donnamegan402@gmail.com
}

How to cite this paper: Egan, D. M., \& Gilic, L. (2021). Using Technological Applications as an Independent Learning Strategy to Support Vocabulary Acquisition for Secondary Students with Learning Disabilities. Open Journal of Modern Linguistics, 11, 529-538. https://doi.org/10.4236/ojml.2021.114040

Received: June 18, 2021

Accepted: July 17, 2021

Published: July 20, 2021

Copyright (อ 2021 by author(s) and Scientific Research Publishing Inc. This work is licensed under the Creative Commons Attribution International License (CC BY 4.0).

http://creativecommons.org/licenses/by/4.0/

\begin{abstract}
Secondary Students, especially students with exceptionalities and an Individualized Education Plan struggle with academic demands, challenges of tiered vocabulary, and the lack of comprehensive vocabulary instruction. Researchers have examined the outcomes of computer-assisted instruction on students' with exceptionalities vocabulary development using various technology. To meet the critical academic vocabulary acquisition needs of secondary students with exceptionalities, research supports the use of technological applications as independent word-learning strategies.
\end{abstract}

\section{Keywords}

Vocabulary, Computer-Assisted Instruction, Students' with Exceptionalities, Independent-Learning Strategy

\section{Introduction}

Vocabulary knowledge is one of the essential components of literacy achievement. Vocabulary knowledge, both oral and written, is critically important for a student's success in school and beyond (Kamil et al., 2008). Research has supported the importance of providing explicit vocabulary instruction to improve students' reading comprehension and writing quality, and their listening and speaking vocabulary (Joshi, 2006; Kame'enui \& Baumann, 2012). Direct classroom instruction often does not provide adequate time for students to remember, understand, apply, analyze, and evaluate new vocabulary words. Direct vocabulary instruction is undoubtedly essential, yet research indicates that a stu- 
dent with a well-developed vocabulary learns many more words indirectly through reading than from classroom instruction (Cunningham \& Stanovich, 1998; Nagy \& Herman, 1984). Vocabulary instruction, at the secondary level, is rolled into content area instruction and therefore gives students a very limited amount of time to learn and acquire word meanings compared to the elementary level. Bryant, Goodwin, Bryant and Higgins (2003), summarized twenty-five years of vocabulary intervention research, calling attention to the unique challenges faced by secondary students with exceptionalities, both struggling readers with 504 Accommodation Plans and students with Individualized Education Plans (IEP) with a classification of Learning disability (LD). Struggling readers at this level of education are often behind their general education peers when it comes to vocabulary knowledge. Bryant et al. (2003) recommended that for these students, vocabulary knowledge is not equal to their general education peers due to their lack of independent word-learning strategies. Today, in the 21st Century, technology is a dominating force; however, its influence has yet to be understood entirely in education (Alemu, 2015).

During the 2014 Future of Education Technology Conference (FETC), CEO Julie Evans revealed major technological trends identified from a 2013 Speak Up Survey from Project Tomorrow. Evans claimed that 89 percent of high school students have access to Internet-connected smartphones, and 60 percent have access to personal computers (Riedel, 2014). Technological devices, such as personal computers, tablets, and cell phones, are now utilized by students as mobile learning tools, thus transforming their learning practices. Educators should use technology and technological devices to motivate and engage students in developing their literacy, vocabulary, and language skills. Instructional technology, such as applications (apps) found on the Internet, is beneficial for all students. These apps individualize learning and customize instruction to meet a student's unique needs and learning rate (Dikusar, 2018). Our students are comfortable in the world of technology and utilize it every day of their lives. They enjoy using the latest tech and trying out the newest cool apps (Marchetta, Masiello, \& Rosenblatt, 2018). An app is any program or group of programs designed for the enduser (Karch, 2019). Application software includes such things as database programs, word processors, Web browsers, and spreadsheets. Also, technology motivates students to be more engaged in reading and learning, especially when they interact with the text using interactive technological tools (Traore \& Kyei-Blankson, 2011; Ware, 2008). Based upon the engaging, repetitive, multi-modal nature of technological tools available in the 21st Century, vocabulary apps on a student's personal computer, used as independent word-learning strategies, can provide educators with a powerful tool to support direct instruction and foster vocabulary development for all students, especially those who are struggling readers and learning disabled. The motivation and engagement is already present when student use technology so teachers need to harness that for educational purposes to foster learning. 


\section{Vocabulary Development}

Vocabulary development is the foundation for learning any language; it is acquiring new words to use in daily life. Vocabulary development concentrates on helping students learn the meaning of new words and concepts in various contexts and across all academic content areas. Teaching students to develop vocabulary means providing explicit instruction on essential words from the text and providing them with strategies to support learning word meanings independently. Vocabulary is acquired incidentally, through indirect exposure to words and intentionally, through explicit instruction in specific words and word-learning strategies (Alemi \& Taxebi, 2011). As students grow, it is critical for both their oral and written vocabulary to expand, allowing them to comprehend increasingly complex grade-level text (Kamil et al., 2008; Loftus \& Coyne, 2013).

\section{Challenges to Vocabulary Development for Struggling Readers and Students Classified with a Learning Disability}

A struggling reader is a student who has been identified, through standardized assessments, as reading below their current grade level. He/She has trouble when reading grade-appropriate texts. The National Joint Committee on Learning Disabilities (NJCLD) defines Learning Disabilities (LD) as a general term that refers to a mixed group of disorders revealed through substantial difficulties in the acquisition and use of listening, speaking, reading, writing, reasoning, or mathematical abilities (American Speech-Language-Hearing Association, 1991). According to the US Department of Education, in 2013-14, the number of children ages 3 - 21 receiving special education services was 6.5 million, or about 13 percent of all public-school students. Among students receiving special education services, 35 percent had specific Learning Disabilities, making LD the largest category within the 13 Special Education classifications (IES, 2021).

Students with LD have difficulties with short-term and long-term memory; therefore, they have unique challenges concerning metacognition. Metacognition, the ability to think about one's thinking, is critical to learning, memory, and academic achievement (Sperling, Richmond, Ramsay, \& Klapp, 2012). Lack of metacognitive skills affects students' ability to recognize task requirements, select and implement appropriate strategies, and monitor comprehension (Hallahan, Kauffman, \& Pullen, 2012). Reading comprehension affects every academic subject in school and poses the greatest difficulty for most students with LD. Studies have confirmed that there is a solid connection between vocabulary knowledge and reading comprehension (Baumann et al., 2003). Students, who have an inherent difficulty learning from texts, are at a significant disadvantage in finding academic success (Roberts, Torgesen, Boardman, \& Scammacca, 2008).

Students at the secondary level encounter a plethora of content-rich, contentarea texts. To achieve comprehension of these content-area texts, they must know the meanings, relationships, and contextual interpretations of each new vo- 
cabulary word (Bryant et al., 2003). Evidence-based classroom strategies, such as cooperative learning, direct instruction, and scaffolded instruction (32 ResearchBased Instructional Strategies, 2017), have been infused into traditional class instruction as a direct result of research completed in this area. However, learning-disabled secondary students are still struggling to acquire mastery regarding the content-heavy texts used within their classrooms. Vocabulary development, especially for students with Learning Disabilities, is affected by the number of experiences and opportunities they are given to learn new words. As Kennedy, Deshler and Lloyd (2015) noted, "given traditional general education instructional settings at the secondary level, it is unlikely a student with LD, who struggles with reading, will receive the type and amount of evidence-based reading instruction needed to improve reading skills and make progress within the content's standards" (p. 23).

1) Challenges of Tiered Vocabulary.

Further research for evidence-based practices to teach vocabulary developed the concept of word tiers. According to Beck, McKeown and Omanson (1987), there are three types of vocabulary words; three tiers of vocabulary: a word's frequency of use, complexity, and meaning regulates into which tier the word falls. Tier one consists of basic words such as boy, cat, run, and red. These words seldom require direct instruction and typically do not have multiple meanings. Tier two consists of high frequency, multiple-meaning vocabulary words, and Tier three consists of low-frequency, context-specific vocabulary words. Tier two and three words create a student's academic language, which is most commonly used within the school setting. Academic language is often viewed as a second language because all literate people must learn it to access educational content (Solomon \& Rhodes, 1995). Although we learn oral language, which allows us to speak with one another, learning an academic language is far more complicated because it involves language not customarily used in oral speech (Fang, Schleppegrell, \& Cox, 2006; Zwiers, 2007). Beck et al. (2008) explained, "Tier two words are the words that characterize written text but are not so common in everyday conversation. This means that learners are less likely to run into these words as they listen to daily language. The opportunities to learn Tier two words come mainly from interaction with books. Also, because getting meaning from written context is more difficult than getting meaning from oral contexts, learners are less likely to learn Tier two words on their own in comparison to the words of everyday oral language" (pp. 7-8). Secondary students, especially those with LD, struggle to increase their knowledge of content-specific Tier two and Tier three vocabulary words; this is often due to poor memory skills, the lack of direct instruction, or the ineffective use of word learning strategies (Beck \& McKeown, 2002). A well-developed vocabulary has long been documented as crucial for success in reading. Research has repeatedly acknowledged that vocabulary size is one of the strongest predictors of reading development (National Institute of Child Health and Human Development, 2000). A limited vocabulary is a signifi- 
cant obstacle to the critical literacy skills required of students in secondary schools.

Challenges resulting from the Implementation of the Common Core Standards of Education.

In 2009, the Common Core Standards of Education (CCSE) were implemented in the United States, and New York State adopted in 2011. According to the NYS Board of Education, "The Common Core State Standards for English Language Arts \& Literacy in History/Social Studies, Science, and Technical Subjects ('the Standards') are the culmination of an extended, broad-based effort to fulfill the charge issued by the states to create the next generation of $\mathrm{K}-12$ standards in order to help ensure that all students are college and career ready in literacy no later than the end of high school" (CCSE, 2010). Common Core Curriculum Standards (CCCS)'s development/implementation neglected to make provisions for special-needs services, which in turn significantly increased the achievement gap for millions of children who have mental, emotional, or physical disabilities that affect their classroom learning. In 2017, NYS implemented a revised CCCS, yet these standards still in place in 36 states across the US, thus marginally increasing the achievement gap for students with disabilities each year (https://www.edweek.org, 2018). Those opposed to the CCCS argued that implementing this national program created a "one-size-fits-all framework" (Halladay \& Moses, 2013: p. 33) that stands in grave contrast to the diverse nature of students in schools throughout the United States. The standardized nature of the CCCS assumes all students begin their academic career at the same academic level and will complete it had mastered the same academic standards at the same rate (Tienken, 2011). Using a longitudinal study of students with disabilities aged 7 to 17 , research collected on reading ability found this assumption to be false (Wei, Blackorby, \& Schiller, 2011). Students classified with a disability that negatively affects their academic performance are expected to meet the same increased educational rigor that their classmates without disabilities must meet (Kirkland, 2011). Haager and Vaughn (2013) maintained that the increased academic expectations of the CCCS are negatively affecting the potential for students with disabilities to graduate from high school.

There is currently a paucity of research regarding the long-term effects of implementing the CCCS on students with disabilities, yet Beals (2014) addressed the implications of these standards, with specific reference to students with LD. Beals stated, "though most Common Core goals are abstract and schematic, collectively they constitute a one-size-fits-all approach that, in practice, has severely straight-jacketed America's special-needs students” (p. 1). Beals (2014) further asserted, "now that this general curriculum is being shaped by dozens of gradespecific Common Core standards, and that teachers (including special education teachers) are increasingly expected to align each day's lesson with one or more of these standards, there's even less room for remediation or acceleration" (p. 1). Data from the National Assessment of Educational Progress (NAEP) (2014) indicated that in the US, only $36 \%$ of eighth graders read at a basic level, with vo- 
cabulary cited as one of the primary barriers to reading comprehension; schools with the highest concentration of special-education students saw a 64 percent decrease in reading scores and a 72 percent decline in math scores (NAEP, 2014). Beals (2014) highlights most educators' concerns when attempting to differentiate instruction for their struggling readers and at-risk students; how can they support their exceptional students when their classroom functions under "one-size-fits-all" guidelines and ignores the skill levels and specific needs of these learners?

2) Lack of Comprehensive Vocabulary Instruction.

Kennedy, Deshler and Lloyd (2015) stated: "For students with Learning Disabilities both direction in word meanings and building capacity through the use of strategies are generally needed for successful learning" (p. 23). Stanovich (1986) sheds light on the pivotal issue of adolescents who choose not to read independently. These students go to great lengths to comprehend content-related texts. Stanovich (1986) stated that students who perform at lower levels than their more skilled peers in vocabulary knowledge would fall further and further behind their general education peers as they get older. Building upon the foundational ideas of Hirsch Jr. (2003), research suggests that struggling readers encounter difficulty with classroom texts because comprehension of such texts requires content-specific prior knowledge. The analysis of Faggella-Luby \& Deshler (2008) points to direct instruction as well as activity-based and computer-assisted methods as effective ways to improve vocabulary acquisition. Textbooks used by secondary students often provide too little support for students with LD, as these students may require multiple exposures in various formats to develop deep meaning and achieve understanding (Roberts et al., 2008). Sharon Vaughn stated, "differences in depth of understanding are related to the number of times and the variety of contexts in which a word is encountered and used" (p. 19). Vaughn and others wrote this brief to "provide schools, districts, and states with background knowledge about best practices for older students who struggle to read. It focuses on the reading skills that adolescents need to more fully access content-area curricula and, in turn, secure a productive future" (Boardman, Roberts, Vaughn, Wexler, Murray, Kosanovich, \& Center, 2008: p. 1).

According to Hallahan, Kauffman and Pullen (2012), in 2000 the National Reading Panel synthesized research on how children acquire reading and best practices for reading instruction (National Institute of Child Health and Human Development, 2000). This report identified the five essential components of effective reading instruction, one of which was vocabulary instruction. These authors suggested that research-based strategies, such as content enhancement, graphic organizers, mnemonics, task analysis, direct instruction, and peer tutoring should be used for classroom instruction to support students with LD. Students with LD make up the largest category of special education students. Due to the low occurrence of behavior problems in most LD students, they usually receive instruction in full-inclusion settings, thus alongside their general education 
peers (Hallahan et al., 2012).

\section{Effective Vocabulary Development}

According to Graves (2000), there are four components of an effective vocabulary program: broad or all-embracing independent reading to expand word knowledge, instruction in specific words to enhance comprehension of texts containing those words, instruction in independent word-learning strategies, and word awareness and word-play activities to motivate and augment learning (Graves, 2000). Technology addresses each of Graves' components due to its engaging, repetitive, multi-modal capabilities. Technology provides the ability to customize learning to support each user's unique learning needs. Also, technology provides students with a sense of personal responsibility and control. If the student feels confident in his or her ability to perform well on an academic task in a riskfree environment, the student will more likely try to complete the task independently (Clark, 2013). The ability of a learner to work effectively and independently while still gaining meaning is student-centered and promotes learner independence. Customized instruction for struggling readers and students with LD will lead to learner independence (Padron \& Waxman, 1999; Proctor, Dalton, \& Grisham, 2007). As the importance of vocabulary acquisition connected to reading as a life skill was presented, technological applications have shown to be an evidence-based strategy to enable struggling readers and students with LD to acquire more skill. The vocabulary acquisition needs of secondary students with exceptionalities have shown through research to benefit from the use of technological applications as an independent strategy available to today's teachers. Students can use technological apps independently, both inside and outside of the classroom environment to support classroom instruction. These apps allow students to customize their learning and engage with new vocabulary words multiple times in a variety of contexts, therefore providing a depth of understanding that too often does not occur with classroom instruction alone. Secondary students are preparing for their college entrance exams and will require a robust vocabulary to achieve success with these standardized assessments. The dissemination of this information is needed to provide teachers with the additional evidence-based applications to explore.

\section{Conflicts of Interest}

The authors declare no conflicts of interest regarding the publication of this paper.

\section{References}

32 Research-Based Instructional Strategies (2017, November 14). https://www.teachthought.com/learning/32-research-based-instructional-strategies/

Alemi, M., \& Taxebi, A. (2011). The Influence of Incidental and Intentional Vocabulary Acquisition and Vocabulary Strategy Use of Learning L2 Vocabulary. Journal of Language Teaching and Research, 2, 81-98. https://doi.org/10.4304/jltr.2.1.81-98 
Alemu, B. M. (2015). Integrating ICT into Teaching-Learning Practices: Promise, Challenges, and Future Directions of Higher Educational Institutes. Universal Journal of Educational Research, 3, 170-189. https://doi.org/10.13189/ujer.2015.030303

American Speech-Language-Hearing Association (1991). Learning Disabilities: Issues on Definition. https://www.asha.org/policy/RP1991-00209/

Baumann, J. F., Kame'enui, E. J., \& Ash, G. E. (2003). Research on Vocabulary Instruction: Voltaire Redux. In J. Flood, D. Lapp, J. R. Squire, \& J. M. Jensen (Eds.), Handbook of Research on Teaching the English Language Arts (2nd ed., pp. 752-785). Mahwah, NJ: Lawrence Erlbaum.

Beals, K. (2014). The Common Core Is Tough on Kids with Special Needs. The Atlantic. http://www.theatlantic.com/education/archive/2014/02/the-common-core-is-tough-on -kids-with-special-needs/283973/

Beck, I. L., McKeown, M., \& Omanson, R. (1987). The Effects and Uses of Diverse Vocabulary Instructional Techniques.

Beck, I. L., \& McKeown, M. G. (2002). Questioning the Author: Making Sense of Social Studies. Educational Leadership, 60, 44-47. https://www.readingrockets.org/content/pdfs/ASCD 358 1.pdf

Beck, I. L., McKeown, M. G., \& Kucan, L. (2008). Creating Robust Vocabulary: Frequently Asked Questions \& Extended Examples. New York: Guilford.

Boardman, A. G., Roberts, G., Vaughn, S., Wexler, J., Murray, C. S., Kosanovich, M., \& Center, O. I. (2008). Effective Instruction for Adolescent Struggling Readers: A Practice Brief. Center on Instruction. https://files.eric.ed.gov/fulltext/ED521836.pdf

Bryant, D. P., Goodwin, M., Bryant, B. R., \& Higgins, K. (2003). Vocabulary Instruction for Students with Learning Disabilities: A Review of the Research. Learning Disability Quarterly, 26, 117-128. https://doi.org/10.2307/1593594

Clark, M. (2013). The Use of Technology to Support Vocabulary Development of English Language Learners. Education Masters.

Common Core Standards for ELA/Literacy (CCSE) (2010). https://www.engageny.org/resource/common-core-standards-for-elaliteracy

Cunningham, A. E., \& Stanoovich, K. E. (1998). What Reading Does for the Mind. American Educator/American Federation of Teachers, 2, 1-8.

Dikusar, A. (2018) The Use of Technology in Special Education. eLearning Industry. https://elearningindustry.com/use-of-technology-in-special-education

Faggella-Luby, M. N., \& Deshler, D. D. (2008). Reading Comprehension in Adolescents with LD: What We Know; What We Need to Learn. Learning Disabilities Research and Practice, 23, 70-78. https://doi.org/10.1111/j.1540-5826.2008.00265.x

Fang, Z., Schleppegrell, M. J., \& Cox, B. E. (2006). Understanding the Language Demands of Schooling: Nouns in Academic Registers. Journal of Literacy Research, 38, 247-273. https://doi.org/10.1207/s15548430j1r3803 1

Graves, M. F. (2000). A Vocabulary Program to Complement and Bolster a Middle-Grade Comprehension Program. In B. M. Taylor, M. F. Graves, \& P. Van Den Broek (Eds.), Reading for Meaning: Fostering Comprehension in the Middle Grades (pp. 116-135). New York: Teachers College Press.

Haager, D., \& Vaughn, S. (2013). The Common Core State Standards and Reading: Interpretations and Implications for Elementary Students with Learning Disabilities. Learning Disabilities Research \& Practice, 28, 5-16. https://doi.org/10.1111/ldrp.12000

Halladay, J. L., \& Moses, L. (2013). Using the Common Core Standards to Meet the Needs of Diverse Learners: Challenges and Opportunities. The NERA Journal, 49, 33-43. 
Hallahan, D. P., Kauffman, J. M., \& Pullen, P. C. (2012). Exceptional Learners: An Introduction to Special Education (13th ed.). New York, NY: Pearson Publications.

Hirsch Jr., E. D. (2003). Reading Comprehension Requires Knowledge of the Words and the World: Scientific Insights into the Fourth-Grade-Slump and the Nation's Stagnant Comprehension Scores. American Educator, 27, 10-29.

IES (2021). Annual Reports and Information Staff: Preprimary, Elementary, and Secondary Education: Students with Disabilities. National Center for Education Statistics, Institute for Education Sciences. https://nces.ed.gov/programs/coe/indicator cgg.asp

Joshi, R. M. (2006). Vocabulary: A Critical Component of Comprehension. Reading and Writing Quarterly, 21, 209-219. https://doi.org/10.1080/10573560590949278

Kame'enui, E. J., \& Baumann, J. F. (2012). Vocabulary Instruction: Research to Practice (2nd ed.). New York, NY: Guilford Press.

Kamil, M. L., Borman, G. D., Dole, J., Kral, C. C., Salinger, T., \& Torgesen, J. (2008). Improving Adolescent Literacy: Effective Classroom and Intervention Practices: A Practice Guide (NCEE \#2008-4027). Washington DC: National Center for Education Evaluation and Regional Assistance, Institute of Education Sciences, U.S. Department of Education.

Karch, M. (2019). A Beginner's Guide to Mobile Apps. Lifewire. https://www.lifewire.com/what-are-apps-1616114

Kennedy, M. J., Deshler, D. D., \& Lloyd, J. W. (2015). Effects of Multimedia Vocabulary Instruction on Adolescents with Learning Disabilities. Journal of Learning Disabilities, 48, 22-38. https://doi.org/10.1177/0022219413487406

Kirkland, K. A. J. (2011). Principals' Perceptions of Classroom Structure and Academic Effects: How Middle School Students with Disabilities Are Affected. Doctoral Dissertation, New York: Fordham University.

Loftus, S. M., \& Coyne, M. D. (2013). Vocabulary Instruction within a Multi-Tier Approach. Reading \& Writing: Overcoming Learning Difficulties, 29, 4-19.

https://doi.org/10.1080/10573569.2013.741942

Marchetta, J., Masiello, M., \& Rosenblatt, M. (2018). Preferences and Learning Behaviors of Digital Natives. Northeast Business \& Economics Association Proceedings, 42, 174176.

Nagy, W. E., \& Herman, P. A. (1984). Limitations of Vocabulary Instruction. Cambridge, MA: Illinois University, Urbana Center for the Study of Reading. https://eric.ed.gov/?id=ED248498

National Assessment of Educational Progress (NAEP) (2014). Civics Framework for the 2014 National Assessment of Educational Progress. https://nagb.gov/naep-frameworks/civics/2014-civics-framework.html

National Institute of Child Health and Human Development (2000). Teaching Children to Read: An Evidence-Based Assessment of the Scientific Research Literature on Reading and Its Implications for Reading Instruction (NIH Publication No. 00-4769). Report of the National Reading Panel, Washington DC: U.S. Government Printing Office.

Padron, Y. N., \& Waxman, H. C. (1999). Effective Instructional Practices for English Language Learners. In H. C. Waxman, \& H. J. Walberg (Eds.), New Directions for Teaching Practice and Research (pp. 171-203). Berkeley, CA: McCutchan.

Proctor, C. P., Dalton, B., \& Grisham, D. L. (2007). Scaffolding English Language Learners and Struggling Readers in a Multimedia Hypertext Environment with Embedded Strategy Instruction and Vocabulary Support. Journal of Literacy Research, 39, 71-93. https://doi.org/10.1080/10862960709336758 
Riedel, C. (2014). 10 Major Technology Trends in Education. The Journal. https://thejournal.com/articles/2014/02/03/10-major-technology-trends-in-education.a spx

Roberts, G., Torgensen, J. K., Boardman, A., \& Scammacca, N. (2008). Evidence-Based Strategies for Reading Instruction of Older Students with Learning Disabilities. Learning Disabilities Research and Practice, 23, 63-69.

https://doi.org/10.1111/j.1540-5826.2008.00264.x

Solomon, J., \& Rhodes, N. C. (1995). Conceptualizing Academic Language. Berkeley, CA: University of California, Berkeley, Center for Research on Education, Diversity, and Excellence. https://escholarship.org/uc/item/9802j9tg

Sperling, R. A., Richmond, A. S., Ramsay, C. M., \& Klapp, M. (2012). The Measurement and Predictive Ability of Metacognition in Middle School Learners. Journal of Educational Research, 105, 1-7. https://doi.org/10.1080/00220671.2010.514690

Stanovich, K. E. (1986). Matthew Effects in Reading: Some Consequences of Individual Differences in the Acquisition of Literacy. Reading Research Quarterly, 21, 360-407. https://doi.org/10.1598/RRQ.21.4.1

Tienken, C. H. (2011). Common Core Standards: The Emperor Has No Clothes, or Evidence. Kappa Delta Pi Record, 47, 58-62. https://doi.org/10.1080/00228958.2011.10516562

Traore, M., \& Kyei-Blankson, L. (2011). Using Literature and Multiple Technologies in ESL Instruction. Journal of Language Teaching and Research, 2, 561-568. https://doi.org/10.4304/jltr.2.3.561-568

Ware, C. V. (2008). Visual Thinking for Design. Burlington, MA: Morgan Kauffmann Publications.

Wei, X., Blackorby, J, \& Schiller, E. (2011). Growth in Reading Achievement of Students with Disabilities: Ages 7 to 17. Exceptional Children, 78, 89-106. https://doi.org/10.1177/001440291107800106

Zwiers, J. (2007). Building Academic Language: Essential Practices for Content Classrooms, Grades 5 - 12. San Francisco, CA: Jossey-Bass. 